Холокост и его использование в нравственном воспитании личности

Holocaust and its use in moral education of the personality

Anna Bolucencova, doctor în istorie, conferențiar universitar,

Catedra de ştiințe ale educaţiei, Facultatea de Științe ale Educației și Informatică, UPS Ion Creangă, Chișinău

\section{CZU: 94(=411.16)"1939/1945":37.034}

\section{Резюме}

В современном обществе важно воспитывать в духе уважения и любви ко всем народам мира. Явление Холокоста убедительно доказало необходимость данного направления воспитательной работы. Содержание работы опирается на интеграцию усилий историков, педагогов и всех социальных институтов общества. Необходимо создавать «прививку» всему человеческому сообществу против человеконенавистнической фашистской идеологии.

Ключевые слова: Холокост, историческая память, гуманность.

\section{Abstract}

In modern society, it is important to educate in the spirit of respect and love for all the peoples of the world. The phenomenon of the Holocaust convincingly proved the need for this area of educational work. The content of the work is based on the integration of the efforts of historians, teachers and all social institutions of society. It is necessary to create a "vaccine" for the entire human community against the hateful fascist ideology.

Keywords: Holocaust, historical memory, humanity.

\begin{tabular}{|c|c|c|}
\hline Каждый & момент & исторического \\
\hline развития & по-своему & уникален \\
\hline
\end{tabular}
действительность постоянно высвечивает ту или иную проблему, которая находит своё разрешение, но при этом человечество подвергается, подчас, жесточайшим испытаниям. Одним из самых страшных и кровавых событий XX века стала Вторая мировая война, которую справедливо называют античеловечной, человеконенавистнической. Она затронула судьбы миллионов людей, это было преступление, направленное против всего человечества. Самым ярким проявлением человеконенавистнической идеологии стал Холокост - 
запланированное

уничтожение по

физическое

причинам всех

идеологическим представителей

национальной, этнической, расовой или религиозной группы [2, с. 10]. По точному определению историка С.M. Назарии, Холокост стал общим термином, не ограничивающийся только еврейским опытом во Второй мировой войне. Целью нацистского государства Германии стало тотальное уничтожение еврейского народа. Евреи в фашистской Германии считались биологически самым главным врагом немецкой нации, в физическом существовании евреев видели угрозу чистоте арийской расы. Их вообще считали недостойными жизни и исключали из семьи народов. Гитлеровцы поставили задачу уничтожить всех евреев, которые, по их мнению, были источником всех человеческих бед. В этом смысле нацистский антисемитизм был новым этапом в многовековой истории гонений. Именно поэтому Холокост стал явлением уникальным.

Во время Второй мировой войны нацисты и их пособники уничтожили в различных странах Европы примерно 6 млн. евреев. Из них более 600 тыс. жители Молдовы и близлежащих областей Украины и Румынии, истреблённые румынскими нацистами по приказу «кондукэтора» (вождя) Румынского государства маршала Иона Антонеску [Idem, с. 16]. И это был только первый этап создания «нового мирового порядка». За евреями должны были последовать и другие «неполноценные» нации, в первую очередь славяне. На временно оккупированных территориях СССР эти кровавые замыслы осуществились: вместе с евреями погибли миллионы людей всех национальностей. Именно поэтому проблема Холокоста - это не только чисто еврейская тема, она стала международной и общезначимой для людей всего мира.

Как показал и время и опыт разрешение проблемы связано с ценностями ориентирами. Недаром А. Эйнштейн говорил: «В конечном счёте, основой всех человеческих ценностей служит нравственность». Нравственность человека базируется на морали. Сама же мораль - это система выработанных в обществе норм, правил и требований, которые предъявляются к личности в различных сферах жизни и деятельности. Мораль базируется на двух основных нравственных категориях - «добро» и «зло». Соблюдение моральных требований, их поддержка личностью обычно ассоциируется с добром. Нарушение же моральных норм и правил, 
отступление от них характеризуется как нравственное зло. Понимание этого и побуждает личность вести себя в соответствии с моральными требованиями общества, совершенствовать своё поведение, что одновременно означает и её моральное развитие. При этом важную роль здесь играет сам характер нравственности и её содержание. Так нравственность фашистского тоталитарного государства развращала людей, возбуждала в них человеконенавистничество и вела к деградации личности.

Немецким солдатам и офицерам официально разрешалось творить преступления на захваченной территории СССР. 13 мая 1941 г. германское правительство утвердило директиву «О военной подсудности в районе «Барбаросса» и об особых полномочиях войск», в которой предписывалось применять к советским людям «массовые насильственные меры» и с военных снималась всякая ответственность за преступления против гражданского населения «даже в случаях, когда эти действия одновременно составляют воинское преступление». В созданной для личного состава гитлеровской армии «Памятке немецкого солдата» откровенно говорилось: «У тебя нет сердца и нервов, на войне они не нужны.
Уничтожь в себе жалость и сострадание убивай всякого русского, советского, не останавливайся, если перед тобой старик или женщина, девочка или мальчик убивай» $[4$, с. 63$]$. Гитлеровцы планировали уничтожить 11 млн. евреев, но успели только «шесть» миллионов, о чём с сожалением говорил Эйхман, возглавлявший отдел по «еврейским делам» в главном штабе СС.

Необходимо констатировать, что идеи превосходства арийской расы, как крайнее проявление национализма проникло в сознание, привычки фашистских захватчиков, они стали обыденными и именно поэтому привели к ужасающим последствиям. Катастрофа евреев - это уничтожение демографического и культурного центра, существовавшего в Центральной и Восточной Европе около тысячи лет. Это было поражение европейской цивилизации, трагедией общечеловеческого значения.

Осознание этой трагедии связано с исторической памятью. Сама по себе категория «память» не механична. Это творческий процесс. Обычно запоминается то, в чём есть необходимость. С помощью памяти накапливается добрый опыт, образуются традиции, создаются трудовые, бытовые навыки, семейный уклад. Память 
активна. Она не оставляет человека равнодушным, бездеятельным. Она владеет умом, затрагивает эмоции.

Память противостоит уничтожающей силе времени. Это свойство памяти очень важное. Принято делить время на прошедшее, настоящее и будущее. Но, благодаря памяти прошедшее прочно входит в настоящее, а будущее как бы предугадывается настоящим, соединяется с прошедшим в одну линию. Можно сказать, что память - это преодоление времени, преодоление смерти. В этом величайшее нравственное значение памяти. Ведь «беспамятный» человек это, прежде всего, человек неблагодарный, безответственный, a следовательно - не способный на добрые, бескорыстные поступки.

Безответственность рождается отсутствием сознания что ничто не проходит бесследно, что всё сохраняется в памяти - в собственной и окружающих. Особенно важным в таком убеждении является категория «совесть». Совесть это в основном память, к которой присоединяется моральная оценка совершённого. Но если совершённое не сохраняется в памяти, то не может быть и оценки. Без памяти не может формироваться и совесть как регулятор поведения человека, «компас», позволяющий ориентироваться в общественной жизни, в мире человеческой культуры, в мире социальных ценностей.

Холокост - это событие, которое необходимо знать, помнить и использовать в нравственном воспитании человека повсеместно, в любой стране мира. В данном случае весь воспитательный процесс должен опираться на триаду: «Я помню, я благодарен, я должен». Это предполагает: знание, достоверные факты об этом явлении; сочувствие, сострадание к прошлым печальным страницам истории; личностную оценку, принципиальность, непримиримость, ответственность.

На уровне исторической памяти необходимо пользоваться достоверными источниками, опираться на солидную академическую школу, глубокие и доказательные исследования историков. В Молдове вышли исследования по теме Холокоста у С.Н. Назария (Холокост. Страницы истории (На территории Молдовы и в прилегающих областях Украины, 1941-1944), Кишинёв, 2005); История без мифов. Вторая мировая война: генезис, ход и истоки, Кишинёв, 2010; П.М. Шорникова (Молдавия в годы Второй мировой войны: к 70-летию Великой Победы над фашизмом, Кишинёв, 2014); Н.Ф. Гуцул (Они сражались против фашизма: Боевой 
колокол памяти: 70-летие (со дня Победы над фашизмом): статьи, документы, списки, публикации, Кишинёв, 2014). Bсе эти издания включают огромный пласт архивных документов, воспоминаний, научных публикаций, периодические издания, воспоминания, фотографии, стенограммы и протоколы изучаемого периода истории. Содержание этих научных трудов необходимо умело адаптировать для пропаганды и просвещения людей различных социальных групп и возрастов. Они должны излагаться доступным, выразительным языком и доходчиво объяснять и убеждать людей.

В процессе формирования нравственных чувств необходимо учитывать эмоциональную сферу человека. «При этом моральные требования должны усваиваться личностью не как внешние, а как личностно значимые, внутренне необходимые. Эмоциональная регуляция нравственного развития личности осуществляется посредством оценочной, прогностической и побудительной функцией чувств» $[1$, с. 41]. Эта работа требует специфических приёмов воздействия, целенаправленной организации жизни личности, её собственной деятельности.
В связи с этим хочется остановиться на принципе толерантности. Толерантность понимается как терпимость к чужому образу жизни, поведению, обычаям, чувствам, мнениям, идеям и верованиям. Её рассматривают как черту характера, которая проявляется в умении переносить трудности и в стремлении достичь взаимного понимания и согласовывания различных интересов, убеждений, привычек [3, с. 23].

Воспитание толерантности стало определяющим в национальной политике Западной Европы после Второй мировой войны, как прививка против фашистской идеологии и недопущения Холокоста. Однако мы убеждаемся в том, что этого недостаточно. В настоящей жизни возникают ситуации, когда нельзя терпеть антигуманную идеологию, мириться с пренебрежением национальных традиций в угоду чуждым, привнесённым извне. Необходимо смотреть на проблему намного шире: не толерантность, а уважение с её составляющими - - доброта, доброжелательность, человечность, приветливость, дружественность. Основой этих отношений должна стать заинтересованность, искренность, деликатность и тактичность.

В странах Западной Европы активизировались социальные группы, 
которые не принадлежат этнически к этому региону. В них входят эмигранты и их семьи. Многие из них живут обособленно, не учитывают традиций страны проживания, не уважают веру коренного этноса, противопоставляют свои религиозные убеждения культуре своей новой родины. Например, это явление исламизма во многих странах Европы. Данная ситуация ведёт к социальным противоречиям, выделению своей особой специфики, а следовательно усилению национальных противоречий, зарождению национализма. Здесь важна не политика сосуществования, a совместное уважительное сожительство, которое и предполагает общечеловеческие нормы и правила поведения.

$\begin{array}{ccr}\text { Tолчком к } & \text { переосмыслению } & \text { и } \\ \text { нормированию } & \text { «прививки» } & \text { от } \\ \text { дационализма } & \text { должны } & \text { быть }\end{array}$
убедительные, яркие эмоциональные факторы внешнего воздействия. Необходимо использовать документальное кино. Примером может быть документальный фильм об истории возникновения нацизма в Германии: Михаил Ромм. Обыкновенный фашизм, документальный фильм, киностудия «Мосфильм», 1965; «Под тенью свастики» (режиссёр Светлана Баблевская. Производство компании «Новое решение - МЕДИА, 2014). Это относится и к художественным фильмам, которые талантливо на судьбах конкретных людей раскрывают все ужасы военного лихолетья (Собибор, художественный фильм, драма, режиссёр Константин Хабенский, 2018). Убедительность и достоверность этого визуального воздействия должно формировать у личности потребность противостоять идеологии фашизма. Важно использовать произведения изобразительного искусства (А. Пластов: «Фашист пролетел», 1947; Кукрыниксы: «Таня (Подвиг Зои Космодемьянской)», 1947).

Следующий важный шаг - это включение в деятельность, практическое формирование умений, навыков, привычек поведения, связанных с вырабатываемыми качествами. Исходя из рассматриваемой проблемы, необходимо находить современные и действенные формы такой работы. Как пример, на начальном этапе можно написать работы диагностического характера: «Моё представление о боли», «Что такое несчастье?», «Какие поступки я всегда осуждаю». Это поможет определить уровень сформированности качеств личности. Затем необходимо наметить ряд конкретных дел, участие в которых формирует социальный опыт, развивает способность к проявлению волевых усилий следовать своим нравственным ориентирам, умению преодолевать трудности, препятствия, связанные с соблюдением определённых норм поведения. 
В русле практической работы можно отметить участие в Дне памяти жертв Холокоста ( 27 января - Международный день, принят по решению Генеральной Ассамблеи ООН, 2005 г.). Это связано с событиями 1945 г., когда Красная Армия освободила нацистский лагерь смерти Освенцим. За время его существования в нём погибло от 1,5 до 2,2 млн. человек.

Далее - это проведение фестиваля песен о Великой Отечественной войне, где вспоминается боль всех народов, пострадавших от фашизма, несение вахты памяти у памятников жертвам Холокоста, посещение художественных тематических выставок, заочное посещение через интернет музеев по истории еврейского народа. Необходимо установить в республике Национальный день памяти жертв Холокоста. В этот день во всех образовательных, культурных учреждениях должны проводиться мероприятия, которые убедительно напоминают людям о фашистской идеологии.

В целом, необходимо создать направление в культурной политике государства Молдова, которое бы в системе выработало методику работы по данной проблеме. Основным должно быть следующее её содержание: знание достоверная убедительная информация (раздел школьных учебников с содержанием данного явления, научнопопулярная литература, сайты интернета); формирование отношения к явлению - документальное кино, художественные фильмы, спектакли, посещение художественных выставок, заочное путешествие через интернет в музеи еврейского народа; практические дела - разнообразные формы и методы работы со всем населением республики (акции, конкурсы, викторины, поисковая и краеведческая работа, движение волонтёров, совместные праздники). Необходимо развитие и укрепление еврейской культуры и право на её осуществление наряду с другими на всей территории республики.

\section{Литература}

1. БОГДАНОВ, Е.Н. Нравственные чувства: содержание и функции.//Советская педагогика, 1986, № 4, c. 41 .

2. НАЗАРИЯ С. Холокост. Страницы истории (На прилегающих областях Украины, 1941-1944). Кишинёв, 2005, с. 10.

3. РОЖДЕСТВЕНСКИЙ Ю.В. Словарь терминов (Общеобразовательный тезаурус): Мораль. Нравственность. Этика. M., 2002, c. 23.

4. РОЗАНОВ Г.Л. План «Барбаросса». Замыслы и финал. M., 1970, c. 63. 